\title{
Online Alışveriş Sitesi Kaynaklı Müş̧teri Algılarının Müş̧teri Memnuniyetine Etkilerinin İncelenmesi
}

\section{Investigating The Effects of Customer Perceptions Resulted From Online Shopping Sites On Customer Satisfaction}

\author{
Vildan ATEŞ*
}

\begin{abstract}
Özet
Müşteri memnuniyeti, online alışveriş sitelerinde sürekliliği, karlılı̆̆ ve müşteri bağlllı̆̆ının oluşturulmasında önemli bir yere sahiptir. Bu çalışmada online alışverişs sitelerinden alışveriş yapan müşterilerin memnuniyetini etkileyen online alışveriş sitesi kaynaklı müşteri algılarını belirlemek, bu algılar arasındaki örüntüyü incelemek ve bu kapsamda bir müşteri memnuniyet modeli önermek amaçlanmıştır. İlk olarak alanyazından faydalanılarak müşteri memnuniyetine etki edeceği düşünülen müşteri algıları belirlenmiş ve bir kuramsal model oluşturulmuştur. Daha sonra bu model Gazi Üniversitesi Gazi Eğitim Fakültesi İlköğretim ile Bilgisayar ve Öğretim Teknolojileri Eğitimi (BÖTE) Bölümlerinde okuyan 553 lisans öğrencisinin oluşturduğu çalışma grubundan toplanan verilerle test edilmiştir. Çalışmanın verileri 21 maddeden oluşan Online Alışveriş Müşteri Algıları ve Müşteri Memnuniyeti Ölçeği (OAMA-MMÖ) ile toplanmış ve açımlayıcı faktör analizi (AFA) ve doğrulayıcı faktör analizi (DFA) teknikleri kullanılarak modelin uygunluğu test edilmiştir. Analizler sonucunda müşteri memnuniyetini güvenlik ve müşteri ilişkileri algılarının etkilediği tespit edilmiştir. Müşteri ilişkileri algısının müşteri memnuniyetini en fazla etkileyen faktör olduğu görülmüștür. Sonuç olarak model doğrulanmıș ve bulgular ilgili alanyazın ile karşılaştırılarak araştırmacılar ile yöneticilere öneriler sunulmuştur.
\end{abstract}

Anahtar Kelimeler: Online Alışveriş Siteleri, Müşteri Algıları, Müşteri Hizmetleri, Müşteri Memnuniyeti

\begin{abstract}
Customer satisfaction has an important role providing continuity, profitability of online shopping sites and in the development of customer loyalty. The aim of this study is to determine the effects of customer perceptions arising from online shopping sites' on customers' satisfaction and to reveal a customer satisfaction model related to customer perceptions. Firstly, the indicators of customer satisfaction about online shopping sites and the customer perceptions thought to influence the customer satisfaction were determined. A theoretical model has been developed to explain the relationship between the online shopping sites based costumer perceptions and customer satisfaction. Working group of the study consists of 553 students from the departments of primary education and computer and instructional technology in Gazi Faculty of Education at the Gazi University. A scale named Online Shopping Customer Perceptions and Satisfaction Scale (OSCPSS)) was developed and used for data collection. The analysis of the data obtained in this study was done by using SPSS and LISREL programs. The theoretical model was tested by using the Explanatory Factor Analysis (EFA) and Confirmatory Factor Analysis (CFA) techniques. The results of the analyses have been showed that customers' perceptions about security and customer relations effect customer satisfaction. Customer relationships perception was found to be the most influencing perception of customer satisfaction. Results were compared with literature results and recommendations were presented to researchers and practitioners.
\end{abstract}

Keywords: Online Shopping Sites, Customer Perceptions, Customer Services, Customer Satisfaction

\section{Giriş}

İnternet ve elektronik ticaret (e-ticaret) yirminci yüzyılın sonlarına doğru ortaya çıkan gelişmelerin en önemlilerinden ikisidir. $\mathrm{Bu}$ gelişmeler sonucu geleneksel ticaret yeni teknolojiler aracılığıyla modern ya da e-ticarete dönüşmüştür. Bunun sonucu olarak İnternet üzerinden hem alışveriş yapan müşterilerin sayısında hem de dünya çapında online alışveriş siteleri yoluyla yapılan satışlarda belirgin bir artış göze çarpmaktadır (Akbar ve James, 2014).

Online alışveriş sitelerini kullanan bireylerin de \%75'inin 16-34 yaş aralığında olduğu çeşitli araştırmalar sonucunda rapor edilmiş olup Türkiye'de de 2015 yılı sonu itibarı ile İnternet kullanıcısı sayısı 46 milyona ulaşmıştır. Bu bulgu Türkiye'de her 5 kişiden birinin alışveriş için online alışveriş sitelerini kullandığı anlamına gelmektedir. Diğer ülkelerle karşılaştırıldığında Türkiye'deki 16-34 yaş aralığındaki genç nüfusun online alışveriş sitelerine

\footnotetext{
*Dr., Gazi Üniversitesi, vgirginates@gmail.com
} 
ilgisinin oldukça fazla olduğu söylenebilir (Internet World Stats; E-Commerce News, 2015; TÜBİSAD, 2014; TÜİK).

Müşterilerin online alışveriş sitelerinden satın alma kararları algı, motivasyon, öğrenme, tutum ve inançlar tarafindan etkilenmekte olup (Akbar ve James, 2014) yapılan çalışmalarda müşteri algılarının; müşteri memnuniyeti, güveni ve bağlılığını etkilediği görülmektedir. Alg1 duyu organlarının fiziksel uyarılmasıyla oluşan sinir sistemindeki sinyallerden oluşmakta olup online müşteriler açısından ele alındığında mal veya hizmeti satın alım öncesindeki, alma esnasındaki ve alışveriş sonrasında müşteri tarafından hissedilen ve yapılan yorum ve unsurlar olarak tanımlanabilir (Gümüşay, 2014). Bu doğrultuda yapılan çalışmalardan birinde; müşterilerin algıladıkları teknik güven, site kalitesi, risk, pazar yönelimi, market yönelimi ve kullanıcı Web deneyiminin güven algısını ve müşterilerin e-ticarete katılımını olumlu yönde etkilediği görülmektedir (Corbitt ve diğerleri, 2003). Kim ve diğerleri (2008) tarafindan yapılan çalışmada da araştırmacılar risk, fayda, gizlilik ve güven algıları ile bilgi kalitesi, imaj ve deneyimin müşteri memnuniyetini arttırdığı rapor edilmiştir. Chang ve Chen'de (2009) yaptıkları araştırmada online alışveriş sitelerinin müşteri ara yüzü kalitesinin algılanan güvenliğe etkisi ile ürün değiştirme maliyetlerinin e-ticaret müşteri memnuniyeti ve bağlılığına etkisini araştırmışlardır. Araştırma sonucunda müşterinin kullandığı arayüzün kalitesi, güvenlik algısını arttırırken; ürün değiştirme maliyetleri ile birlikte müşteri memnuniyeti ve bağlılığını da pozitif yönde etkilediği ortaya çıkmıştır. Eid (2011) tarafından yapılan çalışmada, online alışveriş sitesi müşteri güven ve memnuniyetine etki eden faktörlerin kullanıcı arayüzü kalitesi, online alışveriş sitelerinde sunulan bilgi kalitesi, güvenlik ve gizlilik algıları olduğu ifade edilmektedir. Diğer bir çalışmada Treesinthuros (2012) kolay iade süreci, zamanında teslimat, müşteri desteği, iletişim, güvenli ödeme, güvenli alışverişe dikkat çekerken; Yang ve diğerleri (2015) de çalışmalarında toplam risk algısı, kullanım kolaylığı ve fayda algısının müşteri memnuniyet ve bağlılığını etkilediğini vurgulamışlardır. Yapılan bir diğer çalışmada da araştırmacılar gizlilik ve güvenliğin müşterinin online alışveriş sitelerine bağlılığını arttırmada etkili olduğunu rapor etmişlerdir (Quach ve diğerleri, 2016).

Türkiye'de online alışveriş siteleri müşteri memnuniyetini araştıran çalışmalar incelendiğinde bu konuda çok az çalışma olduğu görülmüştür. Yapılan çalışmalarda da müşteri algılarına sınırlı sayıda yer verilmiştir (Barutçu, 2007; Durmuş ve diğerleri, 2013). Türkiye'de online alışveriş sitelerinden alışveriş yapan müşterilerin memnuniyetini etkileyen online alışveriş sitesi kaynaklı müşteri algılarını değerlendiren çalışmaların sayısı yok denecek kadar azdır. $\mathrm{Bu}$ araştırmada online alışveriş sitelerinden alışveriş yapan müşterilerin memnuniyetini etkileyen ve online alışveriş sitesi kaynaklı oluşan müşteri algılarını belirlemek, bu algıların kendi aralarındaki örüntüsünü incelemek ve bu kapsamda müşteri memnuniyetine etki eden müşteri algıları ile ilgili bir model önermektir. Bu çalışmanın problem soruları aşağıdaki şekildedir:

1. Müşterilerde oluşan online alışveriş sitesi kaynaklı gizlilik algısının müşteri memnuniyeti üzerinde bir etkisi var mıdır?

2. Müşterilerde oluşan online alışveriş sitesi kaynaklı güvenlik algısının müşteri memnuniyeti üzerinde bir etkisi var mıdır?

3. Müşterilerde oluşan online alışveriş sitesi kaynaklı cevap verme yeteneği algısının müşteri memnuniyeti üzerinde bir etkisi var mıdır?

4. Müşterilerde oluşan online alışveriş sitesi kaynaklı müşteri hizmetleri algısının müşteri memnuniyeti üzerinde bir etkisi var midır?

5. Gizlilik, güvenlik, cevap verme yeteneği ve müşteri hizmetleri algıları arasında bir ilişki var midir?

İşletme yöneticileri için düşünüldüğünde müşteri memnuniyetini etkileyen müşteri algılarını anlamak yöneticilerin online alışveriş sitelerinde odaklanmaları gereken kilit 
noktalara dikkatlerini çekmede yardımcı olacaktır. Akademik açıdan bakıldığında, bu çalıșma Türkiye bağlamında e-ticaret müşteri memnuniyetine müşteri algılarının etkisinin anlaşılmasında bilgiler sağlamaktadır. Buna ilaveten bu çalışma, müşteri memnuniyeti üzerinde online alışveriş sitesi kaynaklı oluşabilecek müşteri algılarının (gizlilik, güvenlik, cevap verme yeteneği, müşteri hizmetleri) etkisini geliştirmek açısından e-ticaret alanyazınına da değer katmaktadır.

Bu çalışmanın diğer bölümlerinde sırasıyla müşteri memnuniyetini etkileyen algılar ve ilgili çalışmalar, yöntem, bulgular ile araştırmanın sonucu ile öneriler yer almaktadır.

\section{Müşteri Memnuniyetini Etkileyen Algılar ve İlgili Çalışmalar}

$\mathrm{Bu}$ bölümde, müşteri memnuniyetini etkilediği düşünülen ve online alışveriş sitesi kaynaklı oluşan müşteri algılarından gizlilik, güvenlik, cevap verme yeteneği ve müşteri hizmetleri ile ilgili yapılan çalışmalar hakkında bilgiler bulunmaktadır.

\section{Gizlilik}

Müşterilerin online alışveriş sitelerinden gerçekleştirdiği işlemlerde kullandığı kişisel (gizli) bilgilerinin (ad, soyad, e-mail, ev ve işyeri adresleri, kredi kartı numaraları gibi) yetkisiz kullanıma veya açığa çıkarılmaya karşı online alışveriş sitelerinin koruması yönündeki müşteri algısıdır. Online alışveriş siteleri müşterilerinden gizli bilgilerini topladıkları için gizlilik kaybı müşteriler için temel bir endişe kaynağı olup alışverişlerinde kullandıkları kişisel bilgilerinin korunması da çok önemlidir (Kim ve diğerleri, 2008). Yapılan bir araştırmada yer alan ankete katılanların \%92'si online şirketlerin güvenliği sağlamak için söz verseler bile gizlilik özellikle müşterilerinin kişisel bilgilerini koruma konusunda bu şirketlere güvenmediklerini ve bu konuda endişe duyduklarını belirtmişlerdir (Light, 2001). Bu doğrultuda online alışveriş siteleri de alışveriş yapan müşterileri için uygun ve yeterli gizliliği sağlamalıdır (Odom ve diğerleri, 2002; Ramanathan, 2011).

\section{Güvenlik}

Güvenlik, online alışveriş siteleri müşterileri için dikkate alınması ve özen gösterilmesi gereken önemli bir konudur. Güvenlik algısı, online alışveriş sitelerinin güvenlik gereksinimlerini örneğin kimlik doğrulama, bütünlük, şifreleme ve inkâr etmemeyi yerine getirmesi yönündeki müşteri algısı olarak tanımlanmaktadır. Müşteriler online alışverişs sitelerinden alışveriş öncesinde, sırasında ve sonrasında güvenlik özellikleri (güvenlik politikası, güvenlik sözleşmesi, güvenli alışveriş garantisi gibi) ve koruma mekanizmaları (şifreleme, koruma, kimlik doğrulama, güvenli soket katmanı teknolojisi gibi) bulunduğunu gördüklerinde satıcıların güvenlik ihtiyaçlarını karşılamayı amaçladıklarını anlarlar ve olumlu bir güvenlik algısı geliştirirler (Chellappa ve Pavlou, 2002). Chang ve Chen (2009) birçok potansiyel müşterinin online alışveriş sitelerinden alışveriş yapmamasının başlıca nedeninin güvenlik algısı eksikliği olduğunu belirtmişlerdir.

\section{Cevap Verme Yeteneği}

Cevap verme yeteneği, bir şirketin müşterilerinin soru veya sorunları olduğunda hızlı ve istekli bir şekilde hizmet vermesidir (Gefen ve Straubb, 2004; Zeithaml ve diğerleri, 2002). İşletmelerde artan rekabet ve bunun sonucu olarak müşteri taleplerine hızlı cevap verme bir zorunluluk haline gelmiştir. Bu doğrultuda online alışveriş siteleri de müşteri ihtiyaçlarına en kısa sürede cevap verecek tarzda çalışmaları gerekmektedir. Algılanan cevap verme yeteneği, online alışveriş sitelerinin kendisinden kaynaklı hizmet hatasını gidermeye istekli olması ve şikâyetleri çözüme kavuşturan bir mekanizmanın müşterilere sunulması şeklinde tanımlanabilen müşteri algısıdır (Tax ve diğerleri, 1998). Müşterilere cevap vermede yaşanan aksaklıkların en düşük seviyeye indirilmesi yüksek müşteri memnuniyetine yol açacaktır 
(Srinivasan ve diğerleri, 2002). Bu doğrultuda müşteri gereksinimlerini anlamak ve hizmet geliştirmeye dayalı ve duyarlı bir geribildirim mekanizması müşterilerin memnuniyetini arttıracağı açıktır.

\section{Müșteri Hizmetleri}

Müşteri hizmetleri, online alışveriş siteleri müşterilerinin hem anlık işlemlerini hem de uzun süreli müşteri ilişkilerini sağlamak için alışveriș öncesi ve sonrası işlemlerde online olarak gerekli hizmetleri müşterilerine sunmasıdır. Müşteri hizmetleri iki yönlü olup birinci yönü online alışveriş sitelerinin müşteriye sundukları hizmetlerde sorun olmamasına özen gösterilmesidir. İkinci yönü ise bir sorun olduğunda sorunun hemen çözümüne online alışveriş sitelerinin gösterdiği ilgi şeklindedir (Poleretzky ve diğerleri, 1999; Srinivasan ve diğerleri, 2002). Online alışveriş siteleri müşteri hizmetleri tercih edilen ürünlerin kullanılabilirliği ve siparişlerin durumu hakkında bilgilendirir ve istenilen hizmetlerin sağlanmasındaki aksaklıkları en aza indirmek için harcanan çabaların düzeyidir.

\section{Müșteri Memnuniyeti}

Günümüzde işletmelerin rekabet üstünlüğü sağlamasında müşteri memnuniyetinin çok önemli bir yeri olup başarılarının da temelini oluşturmaktadır. (Bitner ve Hubbert, 1994; Su, 2004). Mukhopadhyay ve diğerleri (2008) müşteri memnuniyetinin satış deneyimi ile başladığını ve satış sonrası hizmetlere kadar devam ettiğini vurgulamışladır. Müşteri memnuniyeti müşterilerin tekrar satın almasında, müşteri bağlılığı sağlamasında ve işletmelerin daha fazla kar elde etmesinde anahtar rol oynamaktadır (Reichheld ve diğerleri, 2000). Online alışveriş siteleri müşteri memnuniyeti ise müşterilerin e-mağazalardan bütün beklentilerinin karşılanması olarak tanımlanabilir (Barutçu, 2007). Barutçu'nun (2007) vurguladığı gibi online alışveriş sitelerindeki müşteri memnuniyeti, online alışveriş sitelerinden alışveriş yapan müşterilerin gelecekteki satın alma niyetleri ve kararlarını etkileyen anahtar değişkenlerden biri olarak değerlendirilebilir. Diğer taraftan online alışveriş sitesi müşterileri memnuniyetsizliğinde müşteriler online alışveriş sitelerinden alışveriş yapmayı bırakıp normal dağıtım kanallarına yönelebilirler (Barutçu, 2007). Bu doğrultuda, online alışveriş siteleri için memnun müşterilere sahip olmak son derece önemli ve kritiktir.

\section{Yöntem}

\section{Evren ve Örneklem}

Araştırmanın ulaşılabilir evrenini Gazi Üniversitesi Gazi Eğitim Fakültesi’nde 20152016 öğretim yılı bahar döneminde öğrenim gören öğrenciler oluşturmaktadır. Veri toplama sürecinde gerekli izin için başvurulmuş ve izin sürecine olumlu cevap veren bölümlerdeki çalışmaya gönüllülük esasına göre katılmayı isteyen öğrencilerden veri toplanmıştır. Seçkisiz olmayan örnekleme yöntemlerinden uygun örnekleme yöntemi kullanılarak kuramsal modelinin test edilmesi sürecine Gazi Eğitim Fakültesi İlköğretim ile Bilgisayar ve Öğretim Teknolojileri Eğitimi (BÖTE) Bölümlerinden 553 öğrenci katılmıştır. Araştırmaya katılan öğrencilerin 33'ü BÖTE, 109'u Fen Bilgisi, 104'ü Matematik, 99'u Okul Öncesi, 120'si Sınıf ve 88'i Sosyal Bilgiler Öğretmenliği öğrencisidir.

$\mathrm{Bu}$ tür çalışmalarda katılımcıların üniversite lisans öğrencilerinden seçilmesi bulguların genellenebilirliği gibi durumlar açısından sorgulanabilir olsa da, bu alandaki benzer araştırmalarda emsalleri bulunmaktadır (Udo ve diğerleri, 2010). Yavaş (1994) tutum-davranış ilişkilerinin modellenmesinde ve ölçek geliştirmede lisans öğrencilerinin kullanımının uygun olduğunu ifade etmektedir. Web sitesi kalitesi algıları ile ilgili daha önce yapılan bazı çalışmalar da lisans öğrencilerinin düşüncelerinden yararlanmıştır (Van ve diğerleri, 2004). Buna ilaveten, yapılan birkaç çalışmada da bu çalışmadaki yaş grubuna tekabül eden genç bireylerin yer aldığı görülmektedir. Online alışveriş sitelerinden ürünler hakkında araştırmalar yapmak için daha 
fazla zaman harcama eğilimleri (Sorce ve diğerleri, 2005) ve online alışveriş eğilimlerinden (Taylor ve diğerleri, 2005) dolayı üniversite lisans öğrencilerinin tercih edildiği görülmektedir.

Tablo 1: Araştırmaya Katılan Çalışma Grubunun Özellikleri

\begin{tabular}{|c|c|c|c|c|c|}
\hline Cinsiyeti & Sayı & $\%$ & İnternet Kullanma Süresi (Yıl) & Sayı & $\%$ \\
\hline Kadın & 464 & 83,9 & 1'den az & 1 & 0,2 \\
\hline Erkek & 89 & 16,1 & $\begin{array}{l}1-2 \\
2-3\end{array}$ & $\begin{array}{l}4 \\
27\end{array}$ & $\begin{array}{l}0,7 \\
4,9\end{array}$ \\
\hline Sinıfinız & Sayı & $\%$ & $3-5$ & 62 & 11,2 \\
\hline 1.Sinif & 9 & 1,6 & 5 'ten fazla & 458 & 82,8 \\
\hline 2.Sinif & 215 & 38,9 & & & \\
\hline 3.Sinif & 324 & 58,6 & Günlük İnternet Kullanma Süresi (saat) & Sayı & $\%$ \\
\hline 4.Sinif & 4 & 0,7 & 1 'den az & 35 & 6,3 \\
\hline \multirow[t]{2}{*}{ Diğer Sınıflar } & 1 & 0,2 & $1-3$ & 198 & 35,8 \\
\hline & & & $3-5$ & 139 & 25,1 \\
\hline Anabilim Dalınız & Sayı & $\%$ & $5-7$ & 111 & 20,1 \\
\hline BÖTE & 33 & 6 & $7-9$ & 40 & 7,2 \\
\hline Fen Bilgisi Öğretmenliği & 109 & 19,7 & 9'dan fazla & 30 & 5,4 \\
\hline Matematik Öğretmenliği & 104 & 18,9 & & & \\
\hline Okul Öncesi Öğretmenliği & 99 & 17,9 & Online Alışveriş Sitesi Alışveriş Sıklığı & Sayı & $\%$ \\
\hline Sınıf Öğretmenliği & 120 & 21,7 & Hemen hemen her gün & 1 & 0,2 \\
\hline \multirow[t]{2}{*}{ Sosyal Bilgiler Öğretmenliği } & 88 & 15,9 & Haftada bir kez & 12 & 2,2 \\
\hline & & & Ayda bir kez & 90 & 16,3 \\
\hline Online Alışveriş Sitesi Tercih & Sayı & $\%$ & Yılda birkaç kez & 450 & 81,3 \\
\hline Çeşitlilik & 38 & 6,9 & & & \\
\hline Fiyat Avantaj1 & 130 & 23,4 & & & \\
\hline Kolaylık /Rahatlık & 62 & 11,2 & & & \\
\hline Zamandan Tasarruf & 31 & 5,7 & & & \\
\hline Hepsi & 292 & 52,8 & & & \\
\hline
\end{tabular}

Araştırmaya katılan katılımcıların özellikleri Tablo 1'de görülmektedir. Tablo 1 incelendiğinde katılımcıların 464'ünün $(\% 83,9)$ kadın olduğu görülmektedir. Milli Eğitim Bakanlığı 2015-2016 yılı Milli Eğitim İstatistiklerine göre eğitim fakültelerinde okuyan kadın öğrencilerin sayısı erkeklerin iki katı olduğu görülmektedir (Milli Eğitim İstatistikleri, 2016). Araştırmaya katılan öğrencilerin cinsiyete göre dağılımı Türkiye'deki eğitim fakültelerinin dağılımına paraleldir. Kadın katılımcılarının büyük çoğunluğu da (\%95,5) 20-24 yaş aralığındadır. Katılımcıların \%59’u 3. sınıf öğrencisi olup ilköğretim bölümü anabilim dallarına göre katılımcı sayısı eşit dağılım göstermektedir. İnternet kullanma süresi incelendiğinde yaklaşık \%83'ünün 5 yıldan fazla süredir İnternet kullandıkları görülmektedir. Online alışveriş sitelerinden yapılan alışveriş sıklıkları \%81'lik oran ile yılda birkaç kez olup online alışveriş sitelerini tercih nedenleri ise çeşitlilik, fiyat avantajı, kolaylık /rahatlık, zamandan tasarruf olarak belirtilmektedir.

\section{Kuramsal Modelin Geliştirilmesi}

Modelin geliştirilmesi süreci iki aşamadan oluşmaktadır. Birinci aşamada alanyazındaki çalışmalarda online alışveriş sitelerinden alışveriş yapan müşterilerin memnuniyetini etkileyen müşteri algıları araştırılmıştır. $\mathrm{Bu}$ araştırma sonucuna göre online alışveriş sitesi kaynaklı olduğu düşünülen müşteri algılarının gizlilik, güvenlik, cevap verme yeteneği ve müşteri hizmetleri olduğu görülmüş ve kuramsal model tasarlanmıştır. 


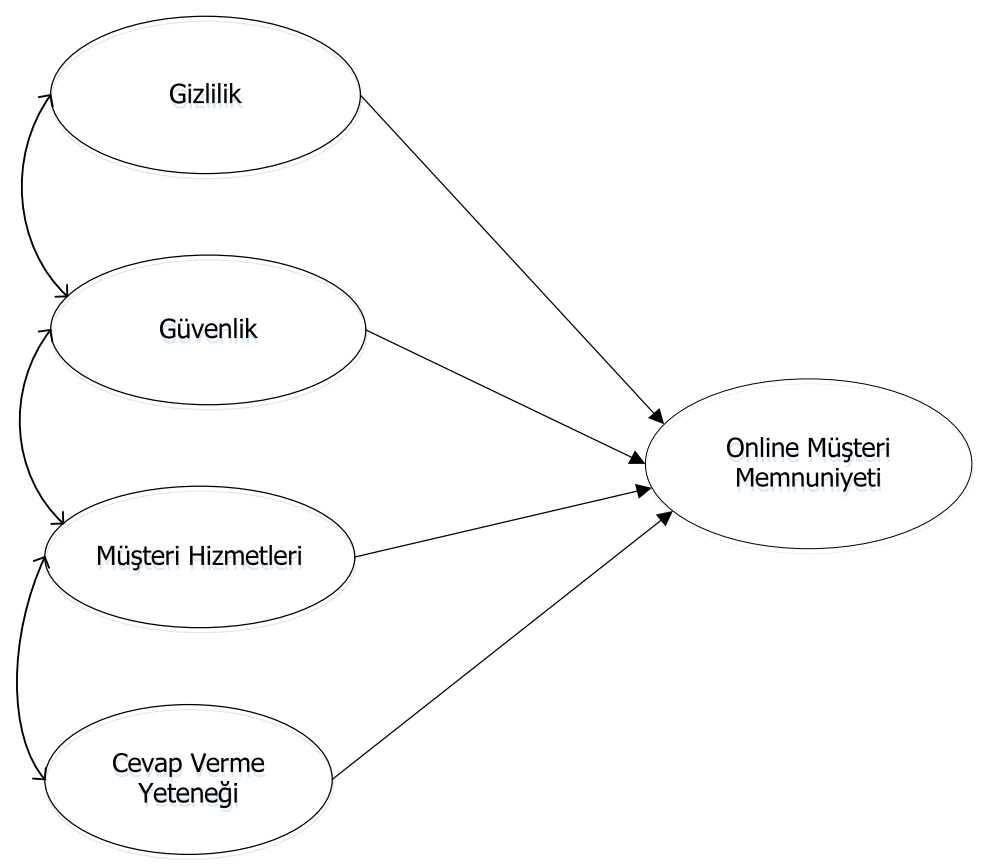

Şekil 1: Kuramsal model

Çalışmanın kuramsal modeli Şekil 1'de görülmektedir. Kuramsal modelde değişkenler arasında iki tür doğrusal ilişki olup bunlar nedensel yönü belirlenmiş ilişki ile nedensel olmayan yönsüz ilişkilerdir. (Hoyle, 1995; Çokluk ve diğerleri, 2010, s. 264). Sonuç olarak araştırmadaki kuramsal modelde dört tane bağımsız gözlenemeyen değişken olup bunlar gizlilik, güvenlik, müşteri hizmetleri ve cevap verme yeteneği algılarıdır. Kuramsal modelde bir tane bağımlı gözlenemeyen değişken online müşteri memnuniyetidir.

\section{Veri Toplama Aracının Geliştirilmesi}

Veri toplama aracı olarak 21 maddeden oluşan Online Alışveriş Müşteri Algıları ve Müşteri Memnuniyeti Ölçeği (OAMA-MMÖ) geliştirilmiştir. Alanyazın araştırması sonucu ilgili makalelerden ölçek maddeleri derlenmiştir. Ölçekte yer alması uygun görülen maddeler için araştırmacılarla elektronik mail aracılıyla iletişime geçilmiş ve gerekli izinler alınmıştır. Tablo 2'de ölçme aracındaki faktörler, madde sayıları ve maddelerin derlendiği kaynaklar görülmektedir.

Tablo 2: Ölçme aracındaki faktörler ve madde sayıları

\begin{tabular}{lcl}
\hline Faktör adı & Madde sayısı & Maddelerin derlendiği \\
\hline Cevap Verme Yeteneği & 3 & Wu (2013) \\
Gizlilik & 5 & Eid (2011) \\
Güvenlik & 4 & Eid (2011) \\
Müşteri Hizmetleri & 5 & Srinivasan vd. (2002) \\
\hline Müşteri Memnuniyeti & 4 & Eid (2011) \\
\hline
\end{tabular}

Maddelerin orijinal dili İngilizce olduğu için dilsel eşdeğerliği sağlamak amaciyla gereken işlemler yapılmıştır. İlk aşamada özgün maddeleri hedef dile yani Türkçeye çevirecek kişiler belirlenmiştir. Belirlenen kişilerden birincisi lisansını İngilizce eğitim yapan üniversitede tamamlamış, yüksek lisans ve doktorasını yurtdışında tamamlamış bir öğretim üyesidir. İkincisi de yüksek lisans ve doktorasını yurtdışında tamamlamış bir öğretim üyesidir. Son olarak üçüncü kişi Üniversitelerarası Dil Sınavı (ÜDS)'ndan yüksek puan almış bir yönetim bilişim sistemleri akademisyenidir. Özgün maddeler Türkçe'ye çevrildikten sonra, ölçek maddeleri üzerinde ortak yapılar alınarak tek bir Türkçe form elde edilmiştir. İkinci aşamada elde edilen Türkçe form maddeleri, Türk Dili ve Edebiyatı bölümündeki iki öğretim 
üyesi tarafından dil bilgisi kuralları, akıcılık ve anlaşılabilirlik gibi kriterlere göre değerlendirilmiştir. Bu işlemden sonra, tekrar uygun düzeltmeler yapılmıştır. Üçüncü aşamada elde edilen Türkçe form maddeleri Gazi Üniversitesi'nde öğrenimine devam eden beş yüksek lisans ve doktora öğrencisine uygulanmıștır. Bu sayede her bir maddenin öğrenciler tarafından anlaşılıp anlaşılmadığı öğrenilmeye çalışılmıştır. Güvenlik algısının birinci ve üçüncü maddelerinde dönütler doğrultusunda değişiklikler yapılmıştır. Bu maddelerin dişında diğer maddelerin anlaşıldığı şeklinde dönütler alınmıştır. Yukarıda detaylı olarak anlatılan üç aşama sonucunda ölçeğin dilsel eşdeğerliliğinin sağlandığına karar verilmiştir. Ölçeğin taslak formunda yer alan maddelerin müşteri memnuniyetini ölçmedeki yeterliliğini ve amaca uygunluğunu belirlemek amacıyla da dört alan uzmanından görüş alınmıştır. Uzmanlardan her bir madde hakkında "Gerekli", "Yararlı ancak gerekli değil" ve "Gerekli değil" șeklinde görüşlerini belirtmeleri ve önerilerde bulunmaları istenmiştir. Öneriler doğrultusunda gerekli düzeltmeler yapılmıştır.

Ölçek cevaplarında çoklu ölçeklerden 7'li Likert ölçeği ile aralık seviyesinde ölçüm yapmak amaçlanmış ve 1-7 şeklinde (1. Kesinlikle katılmıyorum 7. Kesinlikle katılıyorum) ölçeklendirilmiştir.

\section{Verilerin Analizi}

Ölçeğin yapı geçerliği, faktör yapısı, açımlayıcı faktör analizi (AFA) ile incelenmiş ve sosyal bilimler için istatistik programı olan SPSS.17.0 (Statistical Package for the Social Science) paket programı ile yapılmıştır. AFA ile ölçekte yer alan maddelerin ölçtükleri faktörlerin (gözlenemeyen yapıların) keşfedilmesi amaçlanmıştır (Büyüköztürk, 2002). Ölçeğin AFA ile belirlenen faktör yapısının, kuramsal modelin, verilerle ne derece uyum gösterdiğini belirlemek için doğrulayıcı faktör analizi (DFA), LISREL 8.72 bilgisayar programında gerçekleștirilmiștir. Kuramsal modelin gerçek verilerle uyumunu değerlendirmek amacıyla çalışmalarda en sık kullanılan yedi indeks incelenmiştir: Yaklaşık Hataların Ortalama Karekökü (Root Mean Square Error of Approximation, RMSEA), Ortalama Hataların Karekökü (Root Mean Square Residuals, RMR veya RMS), Normlaştırılmamış Uyum İndeksi (Non-Normed Fit Index, NNFI), Karşılaştırmalı Uyum İndeksi (Comparative Fit Index, CFI), Göreli Uyum İndeksi (Relative Fit Index, RFI) ve Düzeltilmiş İyilik Uyum İndeksleri (Adjusted Goodness of Fit Index, AGFI) (Sümer, 2000; Cole ve Maxwell, 2003). Buna ilaveten ki-kare $\left(\chi^{2}\right)$ değeri örneklem büyüklüğünden etkilendiği ve geniş örneklemlerde olumlu sonuç verdiği için bunun yerine analizlerde ki-karenin serbestlik derecesine $(\chi 2 /$ sd) oranına bakılmıştır. (Tabachnick ve Fidell, 2007).

\section{Bulgular}

$\mathrm{Bu}$ bölümde araştırmada toplanan verilerin analizi sonucunda ulaşılan bulgulara yer verilecektir. Araştırmada ulaşılan bulgular üç aşamalı sunulacaktır. İlk aşamada toplanan veri seti için varsayımlar sınanacaktır. İkinci aşamada, ölçeğin ikinci bölümünde önerilen kuramsal modeli doğrulamak için müşteri memnuniyeti ve bu memnuniyeti etkilediği düşünülen müşteri algilarına uygulanan AFA ve DFA ile ilgili bulgular sunulacaktır.

\section{Varsayımların Sınanması}

$\mathrm{Bu}$ araştırmada toplanan veri seti için AFA ve DFA analizlerini gerçekleştirmeden önce veri setinin varsayımları sağlayıp sağlamadıkları test edilmiştir. Analizlerin varsayımları örneklem büyüklüğünün uygunluğu, normallik, doğrusallık, çoklu bağlantı ve tekilliktir (Çokluk ve diğerleri, 2010, s. 206). İlk olarak örneklem büyüklüğünün uygun olup olmadığ incelenmiştir. Değişkenler arası korelasyonun güvenilir olması için yeterince büyük bir örneklem genişliği olmalıdır. Faktör analizi için örneklem büyüklüğü 100 yetersiz, 300 idare eder, 500 iyi ve 1000 mükemmel olarak değerlendirilmektedir (MacCallum, 1999; Çokluk ve 
diğerleri, 2010). Örneklem büyüklüğü için öneriler madde başına 5 kişi olmak üzere en az 200 (Gorsuch, 1983) veya madde başına 10 olmak üzere en az 100 (Streiner, 2013) şeklinde belirtilmektedir. Bu doğrultuda çalışmada kullanılan 21 maddeli müşteri memnuniyet ölçeği için 553 ölçüm uygun bir örneklem büyüklügüüür. İkinci olarak ölçek maddelerinin normal dağılım gösterip göstermediğini test etmek için ölçeğin 21 maddesine Shapiro-Wilk testi uygulanmıştır. Shapiro-Wilks testi güç özelliklerinin daha iyi olduğu ve büyük örneklem hacimlerine (5000 gözleme kadar) uygulanabileceği için tercih edilmiştir. SPSS 17.0' da yapılan analiz sonucu anlamlılık düzeyi $\mathrm{p}<0.05$ düzeyinde anlamlı olmadığı görülmüş ve dağılımın normal olduğuna kararı verilmiştir. Üçüncü incelenen varsayım doğrusallık olup değişkenler arası ve değişkenlerle faktörler arası ilişki doğrusal olmalıdır. Bu durum bütün değişken ve faktörleri kapsamaktadır. Açımlayıcı faktör analizinde öncelikle bütün maddeler arasında korelasyon matrisi incelenerek önemli oranda manidar korelasyonların olup olmadığına bakılmış ve faktör analizinin yapılabilmesine uygunluk gösterir nitelikte manidar ilişkilerin olduğu görülmüştür. Son olarak incelenen varsayımlar çoklu bağlantı ve tekillik olup AFA'da temel bileşenler analizi kullanılacağı ve temel bileşenler analizinde matris tersine çevrilmeyeceği için çoklu bağlantı problemi bulunmadığı sonucuna varılmıştır.

\section{Ölçek Güvenilirlik Analizi Hesaplama Yöntemi}

Ölçek güvenilirlik analizi hesaplama yöntemi olarak güvenirlik katsayısı hesaplama tekniklerinden iç tutarlılık yöntemi seçilmiştir. Bunun içinden de Cronbach alfa iç güvenirlik katsayısı yöntemi kullanılmıştır. Cronbach alfa iç güvenirlik katsayısının bulunabileceği aralıklar aşağıdadır:

1. $0,00 \leq \alpha<0,40$ ise ölçek güvenilir değildir,

2. $0,40 \leq \alpha<0,60$ ise ölçek düşük güvenilirliktedir,

3. $0,60 \leq \alpha<0,80$ ise ölçek oldukça güvenilirdir,

4. $0,80 \leq \alpha<1,00$ ise ölçek yüksel derecede güvenilir bir ölçektir.

Ölçek için hesaplanan Cronbach alfa iç güvenirlik katsayısı $(\alpha=0,95) 0,95$ olup bu değer ölçeğin yüksek derecede güvenilir olduğunu göstermektedir. Her faktöre ait Cronbach alfa iç güvenirlik katsayıları ise; güvenlik algısı için 0,88; müşteri ilişkileri algısı için 0,93; müşteri memnuniyeti için 0,92 'dir. Ölçekteki tüm faktörlerin Cronbach alfa iç güvenirlik katsayısı 0,80 ila 1,00 arasında bir değer olduğundan ölçeğin yüksek derecede güvenilir olduğuna karar verilmiştir.

\section{Açımlayıcı Faktör Analizi İşlemi ve Sonuçları}

Ölçeğin yapı geçerliğini incelemek üzere AFA yapılmıştır. Verilerin faktör analizine uygunluğu Kaiser-Meyer-Olkin (KMO) katsayısı ve Barlett Sphericity testi ile incelenmiştir. KMO $(0,96)$ değeri 0,60'dan yüksek ve Barlett testi incelendiğinde, elde edilen ki-kare $(\chi 2=9951,73, \mathrm{sd}=201, \mathrm{p}=0,000)$ değeri anlamlı olduğu için veriler faktör analizi yapmak için uygun bulunmuştur.

Yapılan AFA analizinde maddelerin faktör yük değerlerinin 0,30'dan yüksek olup olmadığı, birden fazla faktörde aynı anda yüksek yük değeri alıp almadıkları ve ortak faktör varyansları incelenmiştir (Büyüköztürk, 2002). AFA gerçekleştirilirken faktörlerin kendileriyle yüksek ilişski veren maddeleri bulmaları ve faktörleri daha kolay yorumlayabilmek (Büyüköztürk, 2012) için dik döndürme tekniği kullanılmıştır.

Yapılan AFA sonuçları Tablo 3'te görülmektedir. Tablo 3'te ölçek maddeleri ve maddelere ilişkin faktör ortak varyansları, faktör yük değerleri ve her bir faktörün açıkladığı toplam varyans değeri verilmektedir. Kuramsal model beş faktörlü olmasına rağmen yapılan analiz ölçeğin üç faktörden oluşan bir yapıya sahip olduğunu göstermektedir. 
Tablo 3: Faktör Analizi Sonuçları

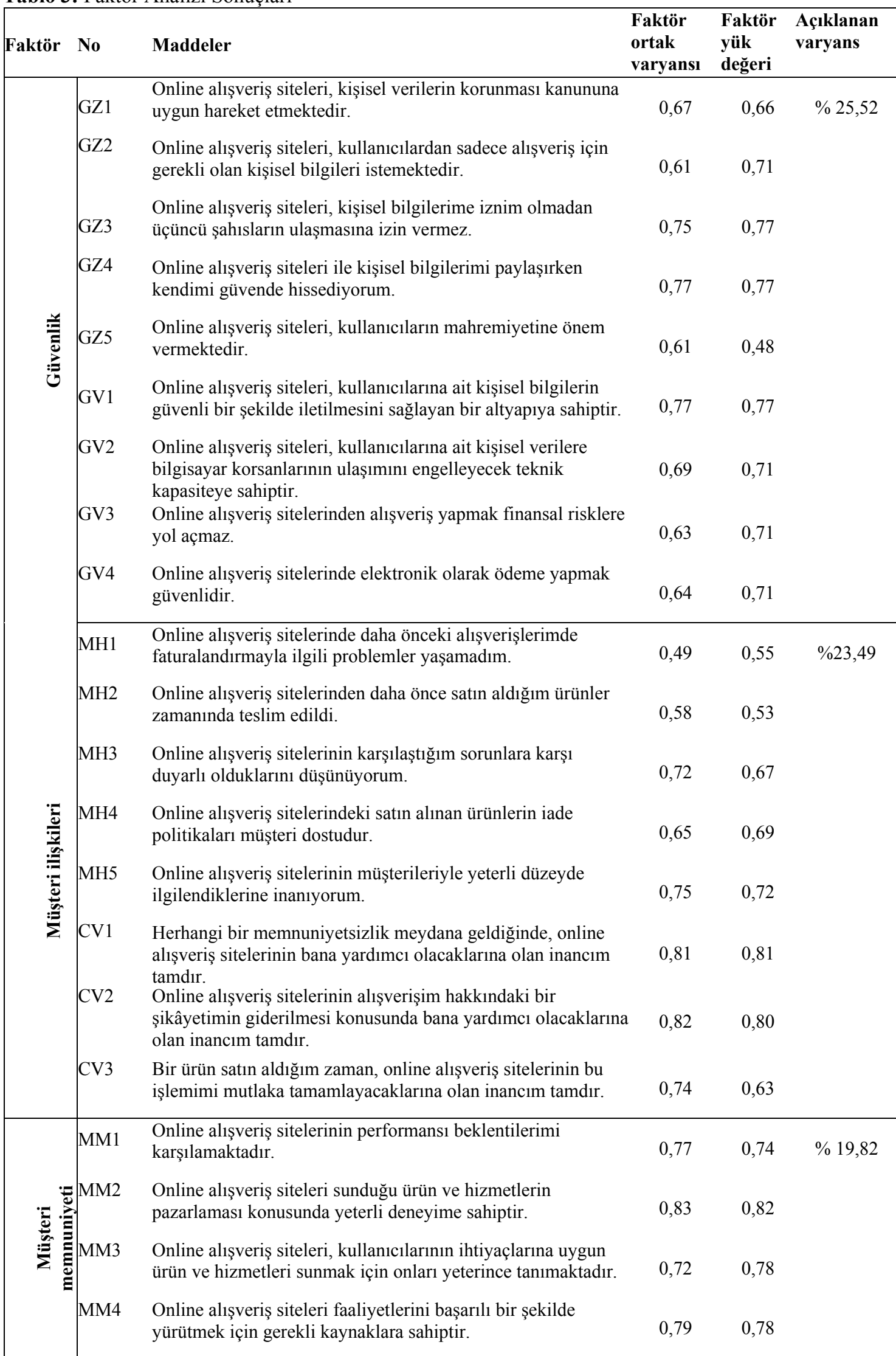

Toplam açıklanan varyans: \% 68,83

Şekil 1'de önerilen kuramsal model gizlilik, güvenlik, müşteri hizmetleri, cevap verme yeteneği ve müşteri memnuniyeti olmak üzere beş faktörden oluşmasına rağmen AFA sonucu 
gizlilik ve güvenlik algılarının bir faktör; müșteri hizmetleri ve cevap verme yeteneği algısının bir faktör altında toplandığı görülmüş̧ür.

Şekil 2'de AFA sonucu oluşan yeni kuramsal model görülmektedir. Bu doğrultuda gizlilik faktörü güvenliğin temel bileşenlerinden biri olduğu için yeni faktör "Güvenlik " olarak yeniden isimlendirilmiştir (Pesen, 2015). Birinci faktör 9 maddeden oluşmakta olup açıkladığ toplam varyans ise $\% 25,52$ 'dir. Müşteri hizmetleri ve cevap verme yeteneği faktörlerinin maddelerinin de tek bir faktör altında toplandığı görülmüştür. "Müşteri ilişkileri" olarak yeniden isimlendirilen ikinci faktör sekiz maddeden oluşmakta ve açıkladığı toplam varyans \%23,49'dur. Kuramsal modelde bulunan ve "Müssteri memnuniyeti" şeklinde isimlendirilmiş olan faktörün değişmeyip dört maddesinin gene kendi faktörü altında toplandığ 1 Tablo 3 'te görülmektedir. $\mathrm{Bu}$ faktörün açıkladığı toplam varyans \%14,27 olup ölçeğin tamamının açıkladığı toplam varyans ise \%68,83'tür.

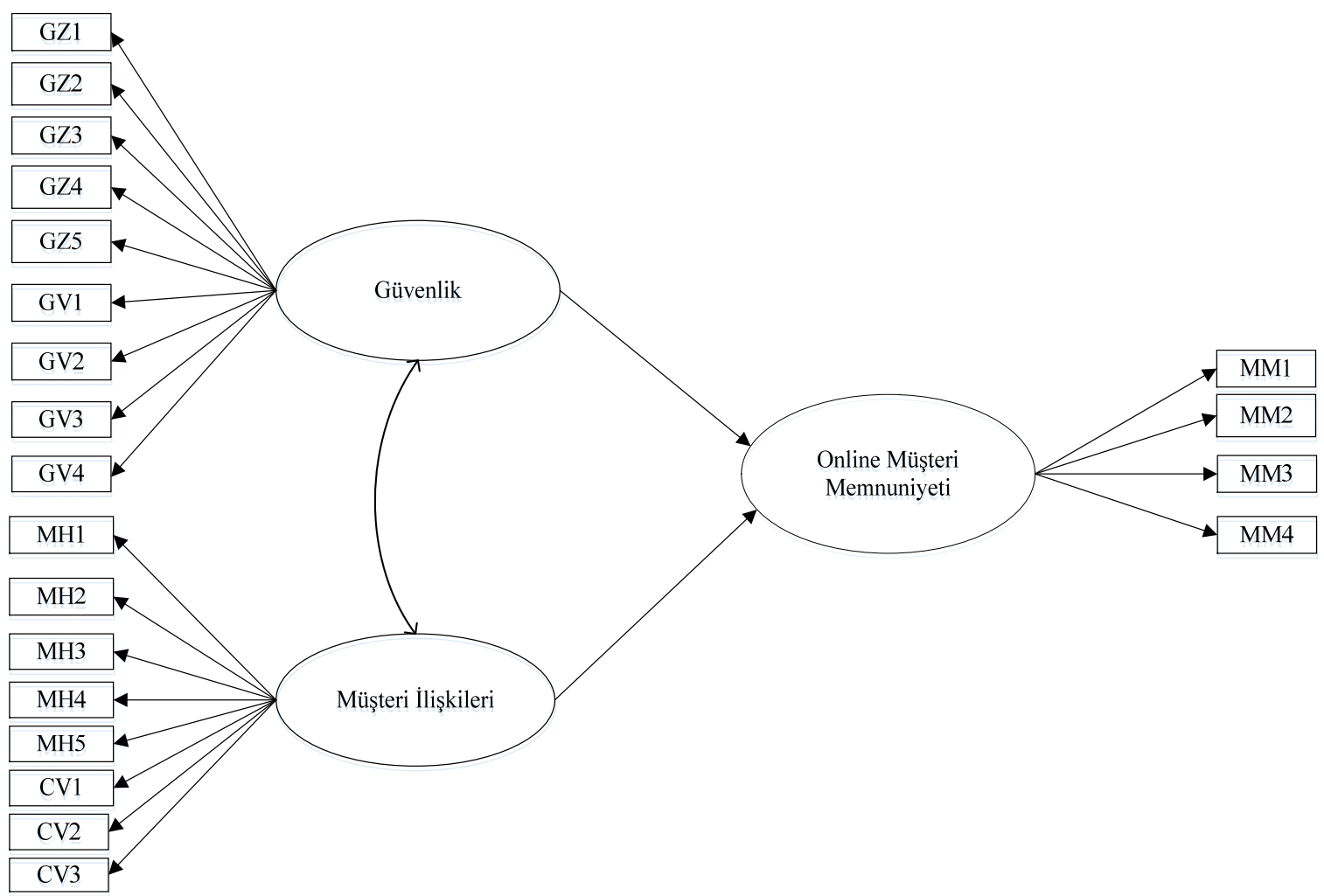

Şekil 2: AFA sonucu oluşan yeni kuramsal model

Bu doğrultuda araştırmanın problem soruları da aşağıdaki şekilde güncellenmiştir:

1. Müşterilerde oluşan online alışveriş sitesi kaynaklı güvenlik algısının müşteri memnuniyeti üzerinde bir etkisi var mıdır?

2. Müşterilerde oluşan online alışveriş sitesi kaynaklı müşteri ilişkileri algısının müşteri memnuniyeti üzerinde bir etkisi var mıdır?

3. Güvenlik ve müşteri ilişkileri algıları arasında bir ilişki var mıdır?

\section{Doğrulayıcı Faktör Analizi İşlemi ve Sonuçları}

Veri analizi için YEM uygulanmış ve DFA LISREL 8.72 bilgisayar programında gerçekleştirilmiştir. AFA ile faktör yapısı ortaya çıkarılan yeni kuramsal model Şekil 2'de görülmektedir. Şekil 2'de görülen yeni kuramsal modelde güvenlik, müşteri ilişkileri ve online müşteri memnuniyeti olmak üzere üç ölçme modeli bulunmaktadır. Üç ölçme modelinin faktör yapısı DFA ile sınanmıştır. 


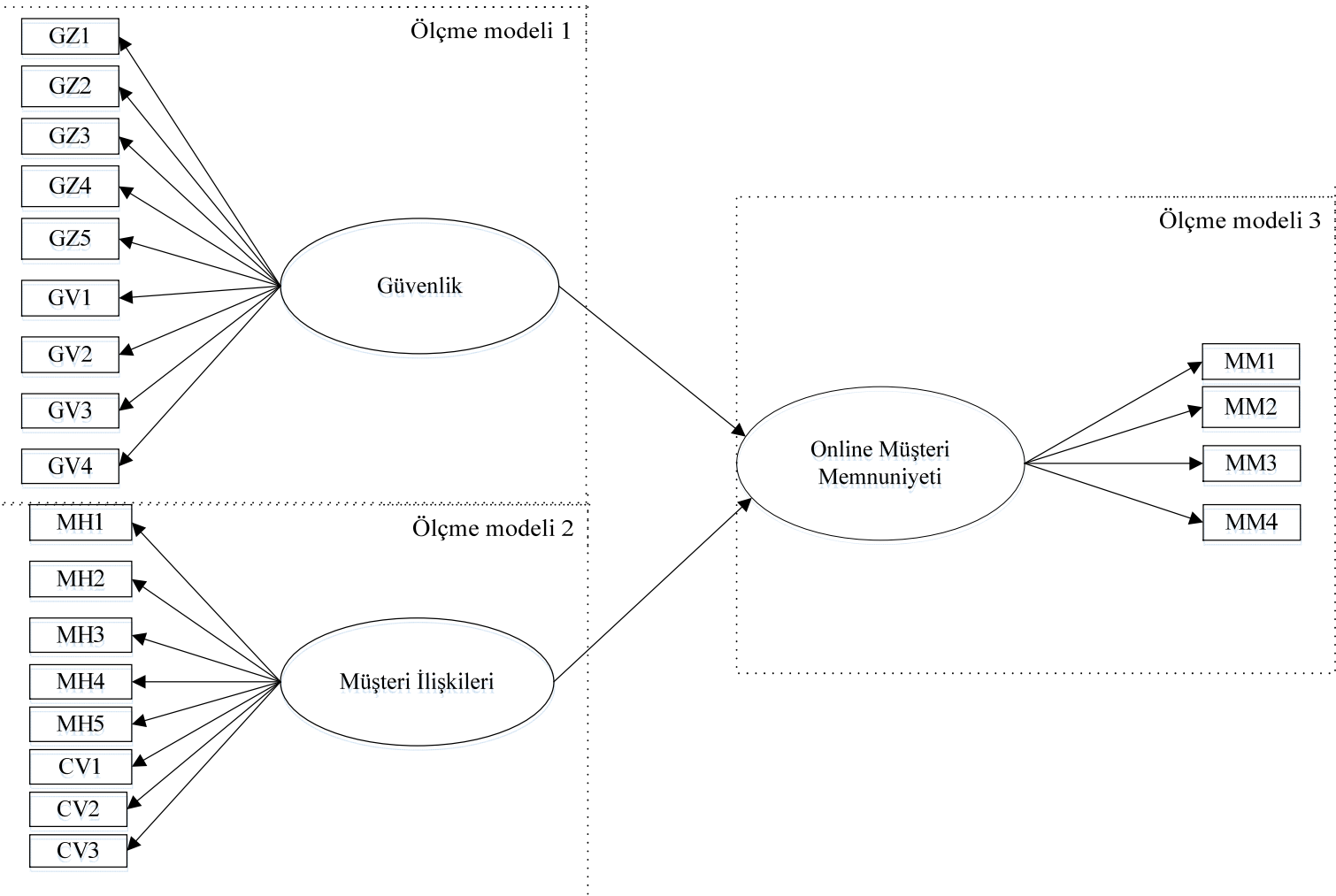

Şekil 3: Kuramsal modeldeki ölçme modelleri

Üç ölçme modelinin analizi için sözdizimi (syntax) dosyası hazırlanmış ve analizler LISREL 8.72 bilgisayar programında gerçekleştirilmiştir. Analizler sonucunda ilk kontrol edilen gözlenen değişkenlerin $t$ değerlerinin manidarlık düzeyidir. Parametre tahminleri 1,96'y1 aşarsa 0,05 düzeyinde ve 2,56'yı aşarsa 0,01 düzeyinde manidardır (Çokluk ve diğerleri, 2010). İkinci kontrol edilen hata varyansları olup ölçme modelindeki hata varyanslarının düşük olması $(<0,90)$ istenen bir durumdur. Son olarak her bir ölçme modelinin doğrulanıp doğrulanmadığını test etmek için uyum indeksleri değerlendirilmiştir.

Tablo 4: Ölçme modellerine ait hata varyansları ve t değerleri

\begin{tabular}{|c|c|c|c|}
\hline Ölçme modelleri & Maddeler & Hata varyansları & t değerleri \\
\hline \multirow{9}{*}{ Güvenlik ölçme modeli } & GZ1 & 0,43 & \multirow{9}{*}{$\begin{array}{l}20,52 \\
18,99 \\
24,53 \\
22,57 \\
27,10 \\
23,74 \\
20,66 \\
18,53 \\
18,90\end{array}$} \\
\hline & GZ2 & 0,49 & \\
\hline & GZ3 & 0,28 & \\
\hline & GZ4 & 0,35 & \\
\hline & GZ5 & 0,18 & \\
\hline & GV1 & 0,31 & \\
\hline & GV2 & 0,42 & \\
\hline & GV3 & 0,51 & \\
\hline & GV4 & 0,49 & \\
\hline \multirow{8}{*}{ Müşteri ilişkileri ölçme modeli } & MH1 & 0,42 & \multirow{8}{*}{$\begin{array}{l}20,68 \\
19,23 \\
24,68 \\
22,34 \\
27,23 \\
23,58 \\
20,08 \\
17,97\end{array}$} \\
\hline & $\mathrm{MH} 2$ & 0,48 & \\
\hline & MH3 & 0,27 & \\
\hline & $\mathrm{MH} 4$ & 0,36 & \\
\hline & MH5 & 0,18 & \\
\hline & CV1 & 0,31 & \\
\hline & $\mathrm{CV} 2$ & 0,44 & \\
\hline & CV3 & 0,53 & \\
\hline \multirow{4}{*}{ Müşteri memnuniyeti ölçme modeli } & MM1 & 0,36 & \multirow{4}{*}{$\begin{array}{l}21,56 \\
20,84 \\
24,74 \\
19,39\end{array}$} \\
\hline & MM2 & 0,39 & \\
\hline & MM3 & 0,23 & \\
\hline & MM4 & 0,45 & \\
\hline
\end{tabular}


Tablo 4'te kuramsal modelde bulunan üç ölçme modeline ait hata varyansları ve t değerleri diğer bir ifadeyle örtük değişkenin gözlenen değişkenleri açıklama oranlarının manidarlık düzeyleri görülmektedir. Tablo 4'e göre tüm maddelerin t değerleri incelendiğinde 0,01 düzeyinde manidar oldukları $(>2,56)$ görülmektedir. Üç ölçme modelinin maddelerinin hata varyansları da 0,90 'dan küçüktür.

Tablo 5: Model uyum indeksleri ve kritik değer eşikleri

\begin{tabular}{|l|l|l|}
\hline Uyum İndeksi & Mükemmel Uyum & İyi Uyum \\
\hline$\chi 2 / \mathrm{sd}$ & $0 \leq \chi^{2 / \mathrm{sd}} \leq 2$ & $2 \leq \chi 2 / \mathrm{sd} \leq 3$ \\
\hline RMSEA & $0 \leq \mathrm{RMSEA} \leq 0.05$ & $0.05 \leq \mathrm{RMSEA} \leq 0.08$ \\
\hline RMR & $0 \leq \mathrm{RMR} \leq 0.05$ & $0.05 \leq \mathrm{RMR} \leq 0.08$ \\
\hline NNFI & $0.95 \leq \mathrm{NNFI} \leq 1.00$ & $0.90 \leq \mathrm{NNFI} \leq 0.95$ \\
\hline CFI & $0.95 \leq \mathrm{CFI} \leq 1.00$ & $0.90 \leq \mathrm{CFI} \leq 0.95$ \\
\hline RFI & $0,95 \leq \mathrm{GFI} \leq 1,00$ & $0,90 \leq \mathrm{GFI} \leq 0,95$ \\
\hline AGFI & $0.95 \leq \mathrm{AGFI} \leq 1.00$ & $0.90 \leq \mathrm{AGFI} \leq 0.95$ \\
\hline
\end{tabular}

Tablo 5'te yapısal modelin uyumunun değerlendirilmesinde kullanılan uyum indeksleri ve kritik değer eşikleri bulunmaktadır (Bollen, 1986; Bentler, 1990, s. 240; Segar ve Grover, 1993; Chin ve Todd, 1995; Hair, 1998; Gefen, 2000; Sümer, 2000; Cheng, 2001; Kline, 2005; Weston, 2006; Tabachnick ve Fidell, 2007; Yılmaz ve Çelik, 2009, s. 29). Tablo 5'te görülen eşik değerlerine göre modellerin uyum indeksleri değerlendirilmiştir.

Tablo 6: Ölçme modellerinin uyum indeksleri

\begin{tabular}{|l|c|c|c|c|c|c|c|}
\hline Ölçme modelleri & $\chi 2 / s d$ & RMSEA & RMR & NNFI & CFI & RFI & AGFI \\
\hline Güvenlik ölçme modeli & 4,4 & 0,09 & 0,09 & 0,98 & 0,99 & 0,97 & 0,90 \\
\hline Müşteri ilişkileri ölçme modeli & 3,8 & 0,07 & 0,07 & 0,99 & 0,99 & 0,98 & 0,94 \\
\hline Müşteri memnuniyeti ölçme modeli & 4,4 & 0,07 & 0,06 & 0,99 & 1.00 & 0,98 & 0,96 \\
\hline
\end{tabular}

Tablo 6'da güvenlik, müșteri ilișkileri ve müșteri memnuniyeti ölçme modellerine ait uyum indeksleri görülmektedir. Güvenlik ölçme modeli için Tablo 6 'da bulunan $\chi 2 / \operatorname{sd}$ oran 14,5 $(8,9 / 2)$ ile kabul edilebilir uyum göstermektedir. Diğer uyum indeksleri incelendiğinde RMSEA ve RMR 0,09 ve AGFI 0,90 değeri ile kabul edilebilir uyuma karşılık gelirken; NNFI, CFI ve RFI değerleri sırası ile 0,98; 0,99 ve 0,97 olup mükemmel uyuma karşılık geldiği ifade edilebilir. Sonuç olarak güvenlik ölçme modelinin dokuz maddeden oluşan bir faktörlü yapısı ölçme modeli olarak doğrulanabilir.

Müşteri ilişkileri ölçme modeli uyum indeksleri incelendiğinde $\chi 2 /$ sd oranı 3,8 $(64,78 / 17)$ olup kabul edilebilir uyum aralığındadır. RMSEA ve RMR değeri 0,07 ve AGFI'nin 0,94 ile iyi uyum; NNFI, CFI 0,99 ve RFI'ın 0,98 değeri ile mükemmel uyum göstermektedir. Sekiz maddeden oluşan müşteri ilişkileri ölçme modeli doğrulanmıştır.

Üçüncü ölçme modeli olan müşteri memnuniyeti ölçme modeli $\chi 2 / s d$ oranı 4,4 (8,9/2) olup kabul edilebilir uyum göstermektedir. RMSEA ve RMR uyum indeksleri 0,07 ve 0,06 ile iyi uyum göstermektedir. Diğer taraftan NNFI, CFI ve RFI değerleri sırasılla 0,$99 ; 1,00$ ve 0,98 olup mükemmel uyuma karşılık gelmektedir. Bu uyum indeksleri değerlendirildiğinde dört maddeden oluşan müşteri memnuniyeti ölçme modeli de doğrulanmıştır.

Kuramsal modeldeki üç ölçme modeli doğrulandıktan sonra bu çalışmada önerilen ve Şekil 2'de görülen kuramsal modele doğrulayıcı faktör analizi uygulanmıştır. DFA ile sınanan kuramsal modelin hata varyansları 0,17 ile 0,49 değerleri arasındadır. Güvenlik ile müşteri 
memnuniyeti algıları arasındaki $\mathrm{t}$ değeri 3,82; müşteri ilişkileri ile müşteri memnuniyeti arasındaki t değeri 10,72 olup 0,01 düzeyinde manidardır. Kuramsal modelin uyum indeksleri incelendiğinde ise $\chi 2 /$ sd oranı 4,3 (799/182) olup kabul edilebilir uyum aralığındadır. Diğer uyum indeksleri değerleri ise RMSEA 0,07; RMR 0,01 ve AGFI 0,85 değerleri ile kabul edilebilir uyuma sahipken; NNFI ve CFI 0,98 ile RFI 0,97 ile mükemmel uyum göstermektedir. $\mathrm{Bu}$ çerçevede sonuç olarak, yeni kuramsal model doğrulanmıştır.

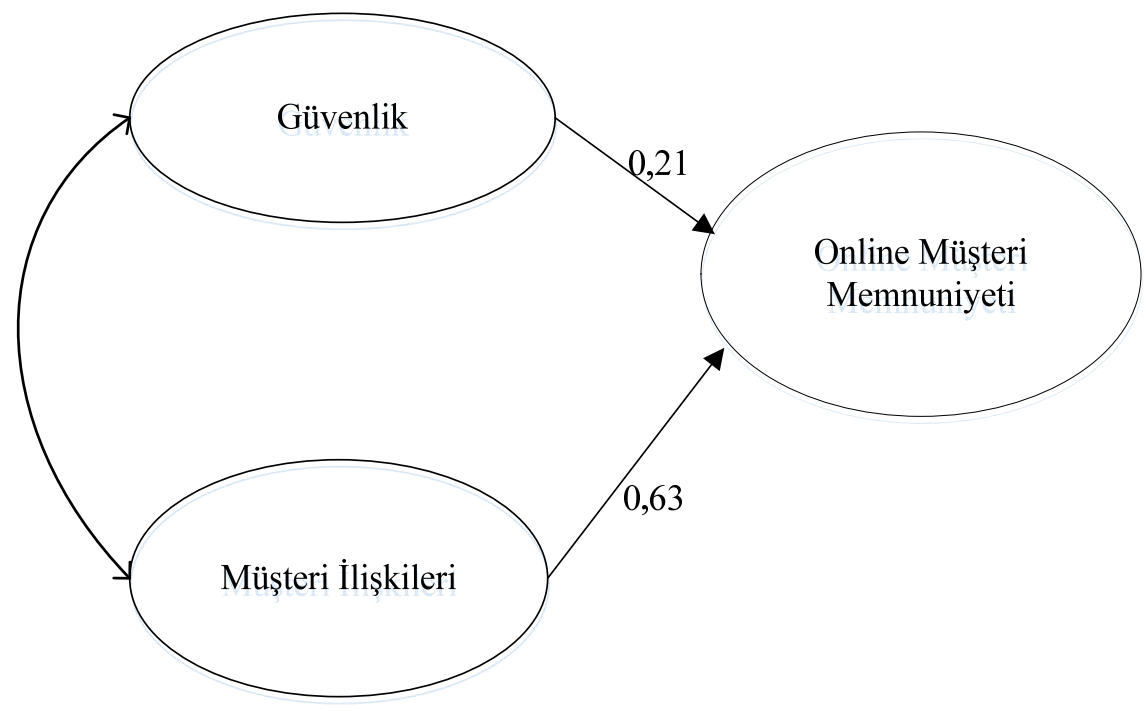

Şekil 4: Kuramsal modeldeki değişkenler arası ilişkiler

Şekil 4'e göre müşterilerde oluşan online alışveriş sitesi kaynaklı güvenlik ve müşteri ilişkileri algıları ile müşteri memnuniyeti arasında bir ilişsinin olduğu görülmektedir. Şekil 4'te görüldüğü gibi güvenlik ve online müşteri memnuniyeti arasındaki ilişki katsayısı 0,21 ve müşteri ilişkileri ve online müşteri memnuniyeti arasındaki ilişki katsayısı 0,63 olarak tahmin edilmiştir. Güvenlik ve müşteri ilişkileri gizil değişkenlerindeki bir birimlik bir artış online müşteri memnuniyeti bağımlı gizil değişkenini sırasıyla 0,21'lik ve 0,63'lük bir artışla, etkilemektedir. Bu katsayılar pozitif ve $\% 1$ anlam düzeyinde istatistiksel olarak anlamlıdır. $\mathrm{Bu}$ katsayılardan hareketle müşterilerin güvenlik ve müşteri ilişkileri algıları arttıkça müşterilerin memnuniyetinin artacağı yorumu yapılabilir. Buna ilaveten güvenlik ile müşteri ilişkileri algıları arasında $0,75^{\prime}$ lik bir ilişki katsayısı bulunmuş olup yüksek ilişki $(>0,71)$ olduğu belirlenmiştir (Büyüköztürk, 2012; Yılmaz ve Çelik, 2009).

Kelloway'e göre (1998) belirleme katsayısının da $\left(\mathrm{R}^{2}\right)$ uyum indeksleri gibi araştırma sonucunda rapor edilmesi gerekmektedir. $\mathrm{R}^{2}$ açıklanan varyans olup gözlenen değişkenlerin gizil değişkenlerdeki gözlenen değişimlerin ne kadarının açıkladığını belirten katsayıdır (Haşlaman ve Aşkar, 2007). Bu çalışmadaki belirleme katsayısı $\left(R^{2}\right)$ 0,63 olup güvenlik algısı ile müşteri ilişkileri algısı beraber online alışveriş sitelerinden alışveriş yapan müşterilerin memnuniyetinin \%63’ünü açıklamaktadır.

\section{Tartışma ve Sonuç}

$\mathrm{Bu}$ bölümde, araştırma kapsamında elde edilen bulguların sonuçları tartışılmış ve bu doğrultuda önerilere yer verilmiştir.

$\mathrm{Bu}$ çalışmada, müşteri memnuniyetini etkileyen online alışveriş sitesi kaynaklı müşteri algılarının belirlenmesi, aralarındaki örüntünün tespiti ve müşteri algıları doğrultusunda bir müşteri memnuniyet modelinin ortaya çıkarılması amaçlanmıştır. Yapılan alanyazın taraması sonucunda araştırmanın ilk kuramsal modeline ulaşılmıştır. Bu modelde bulunan ve müşteri memnuniyetini etkilediği düşünülen gizlilik, güvenlik, cevap verme yeteneği ile müşteri hizmetleri algıları yapılan AFA analizi sonucunda yeniden yapılandırılmıştır. Yapılandırılan 
yeni kuramsal model ile bu modelde yer alan üç ölçme modeli DFA ile doğrulanmış ve müşteri memnuniyet modeline ulaşılmıştır.

Yeni kuramsal modeldeki güvenlik ve müşteri ilişkileri algılarının müşteri memnuniyeti üzerinde etkisi olduğu görülmüştür. Güvenlik algısı 0,21 oranında müşteri memnuniyetini etkilemekte olup yapılan çalışmalarda da güvenlik algısının müşteri memnuniyetinde belirleyici rol oynadığ 1 vurgulanmaktadır (Kim ve diğerleri, 2008; Chang ve Chen, 2009; Eid, 2011; Chen, 2012). Zeithaml ve diğerleri (2000) yaptıkları çalışmada diğer faktörlerin yanında olumlu gizlilik ve güvenlik algılarının müşteri memnuniyetini etkilediğine dikkat çekmişlerdir. Bir diğer çalışmada Teo ve Liu 'da (2007) güveni müşteri kaynaklı ve satıcı kaynaklı olmak üzere iki farklı gruba ayırmış ve her birinin alt bileşenleri ile risk algısının genel müşteri memnuniyet ve güvenini etkilediğini belirtmişlerdir. Aynı doğrultuda Eid (2011) de çalışmasında güvenlik ve gizlilik algılarına müşteri memnuniyetini etkileyen faktörler içerisinde rapor etmiş̧lerdir.

Analizler sonucu müşteri ilişkileri algısının $(0,63)$ güvenlik algısından $(0,21)$ daha fazla müşteri memnuniyetini arttırdığı ortaya çıkmıştır. Buna ilaveten müşteri memnuniyetini etkileyen güvenlik ve müşteri ilişkileri algıları arasında bir örüntü bulunmaktadır. Buna paralel olarak Barutçu (2007) yaptığı çalışma sonucunda müşteri memnuniyetini etkileyen önemli faktörleri sıralamış ve maliyetten sonra gelenin e-müşteri hizmetleri kalitesi olduğunu rapor etmiştir. Kassim ve Abdullah (2008) da müşterinin aldığı müşteri hizmetleri kalitesi ile cevap verme yeteneği; Pan ve diğerleri (2012) müşteri ve ürün ilişkili hizmetlerin müşteri memnuniyetinde etkili olduğunu vurgulamışlardır. $\mathrm{Bu}$ sonuca paralel bir diğer çalışma Treesinthuros (2012) tarafından yapılmış ve kolay iade süreci, zamanında teslimat, müşteri desteği, iletişim, güvenli ödeme, güvenli alışverişin müşteri memnuniyet ve güvenini arttırdığ rapor edilmiştir. Bir diğer güncel çalışma Quach ve diğerleri (2016) tarafından yapılmış olup İnternet servis sağlayıcı hizmetinin kalitesi, müşteri hizmetleri, teknik destek, gizlilik ve güvenliğin müşteri memnuniyet ve bağlılığı etkilediği görülmüştür. Sonuç olarak alanyazın incelendiğinde de güvenlik ve müşteri ilişkileri algılarının müşteri memnuniyetinde etkili faktörler olduğu açıktır.

Bu çalışmanın sonucu özellikle online alışveriş sitesi kuracak ve sürece yeni başlayacak şirketlere yardımcı olacak ve müşteri ilişkileri ve güvenlik konularına dikkat çekecektir. Bu çalışma sonucuna göre online alışveriş site yöneticileri ilk olarak müşteri ilişkileri sonucu şekillenecek olan müşteri ilişkileri algısına dikkat etmeleri gerekmektedir. Online alışveriş sitelerinin, fiziki dünyayla en güçlü şekilde rekabet edebilmeleri için, müşteri hizmetlerine önem vermeleri ve onların sorunlarını mümkün olduğunca çabuk halletmeleri gerekmektedir. Müşterilerin bakış açısını benimseyerek ve analiz ederek müşteri ilişkileri sonucu oluşan algılarını anlamaları ve yönetmeleri önemlidir. Türkiye İstatistik Kurumu (TÜİK) Girişimlerde Bilişim Teknolojileri Kullanım Araştırması istatistikleri incelendiğinde, ülkemizde girişimlerin müşteri ilişkileri yönetimi (MIY) programı kullanım oranının \%9 olduğu görülmektedir (TÜİK). Dünya genelinde MIY kullanım oranının 2015 yılı sonunda \%56'dan \%74'e yükseldiği düşünüldüğünde Türkiye genel oranının düşük olduğu sonucuna varılabilir (SuperOffice, 2016). Bu doğrultuda MiY programı kullanımı teşvik edilmeli ve online alışveriş siteleri ihtiyaçları ve bütçeleri doğrultusunda bir MiY programı kullanmalıdır.

Online alışveriş site yöneticilerinin ikinci olarak dikkat etmeleri gereken konu müşterilerde oluşacak güvenlik algısıdır. Günümüz online alışveriş sitelerinde güvenlik stratejik bir özellik olmaktan çıkmış ve müşteri memnuniyeti için temel bir gereklilik halini almıştır. Bu doğrultuda online alışveriş siteleri de müşterilerinin kişisel verilerin korunması konusundaki mevzuata uygun hareket etmeli ve bu mevzuat doğrultusunda gerekli yönetimsel ve teknik düzenlemeleri yapmalıdır. Güvenli Soket Katmanı (Secure Socket Layer (SSL)) protokolü kullanarak İnternet üzerinden şifrelenmiş güvenli veri iletişimini sağlamalıdırlar. Online alışveriş siteleri veri tabanlarındaki eski kayıtları temizlemeli ve alışveriş süreci için 
ihtiyaç duyulabilecek minimum miktarda veri tutmalıdırlar. Buna ilaveten herhangi bir dolandırıcılık riskine karşı adres ve kredi kartı doğrulama sistemlerini kullanmalıdırlar. Geleneksel dükkanlarda kullanılan kameralar gibi online alışveriş siteleri de gerçek zamanlı analiz araçları kullanılarak alışveriş sitesindeki etkinlikler izlenmeli ve raporlanmalıdır. Online alışveriş siteleri Dağınık Hizmet Engelleme (DDoS) saldırılarından korunmak için bulut tabanlı DDoS koruma kullanabilirler. Yeni teknolojilerin ses tanıma ve dokunmatik cihazlar gibi kullanımı da müşteri memnuniyetini etkileyip arttırabilir.

Son olarak, bu çalışma bazı sınırlılıklar dâhilinde gerçekleştirilmiştir. Bu sınırlılıklar, Gazi Üniversitesi Gazi Eğitim Fakültesi İlköğretim ve BÖTE bölümlerinde öğrenim gören 553 öğrenci ve online alışveriş sitesi kaynaklı oluşan müşteri algıları olarak sıralanabilir.

Gelecekte yapılabilecek çalışmalarda müşteri algılarının tümü incelenebilir. Bu çalışma kapsamında sadece online alışveriş sitesi kaynaklı oluşan müşteri algıları ile üniversite öğrencileri bulunduğundan gelecek çalışmalarda farklı yaş gruplarındaki müşteriler veya spesifik bir online alışveriş sitesi ile gerçekleştirilebilir.

\section{Kaynakça}

Akbar, S. ve James, P.T.J. (2014). Consumers' attitude towards online shopping: Factors influencing employees of crazy domains to shop online. Journal of Management and Marketing Research, 14 (1), 1-11.

Barutçu, S. (2007). E-Mağazalardan Alış-Verişlerde E-Müşteri Tutumları ve E-Müşteri Memnuniyetini Etkileyen Faktörler. Selçuk Üniversitesi, I.I.B.F. Sosyal ve Ekonomik Araştırmalar Dergisi, 7 (14), 219-238.

Bitner, M.J. ve Hubbert, A.R. (1994). Encounter satisfaction versus overall satisfaction versus quality. R.T.Rust ve R.L.Oliver (Der.) New Directions in Theory and Practice: İçinde 72-94. USA: Sage.

Büyüköztürk, Ş. (2002). Faktör Analizi: Temel Kavramlar ve Ölçek Geliştirmede Kullanımı. Kuram ve Uygulamada Eğitim Yönetimi, 32, 470-483.

Büyüköztürk, Ş. (2012). Sosyal Bilimler için Veri Analizi El Kitabı İstatistik, Araştırma Deseni SPSS Uygulamalarl ve Yorum (16. Bask1). Ankara: Pegem Akademi Yayınc1lık, 52.

Chang, H. H. ve Chen, S.W. (2009). Consumer perception of interface quality, security, and loyalty in electronic commerce. Information ve Management, 46, 411-417.

Chellappa, R.K. ve Pavlou, P.A. (2002). Consumer trust in electronic commerce transactions. Logistics Information Management, 15 (5/6), 358-368.

Chen, S. (2012). The customer satisfaction-loyalty relation in an interactive e-service setting: The mediators. Journal of Retailing and Consumer Services 19, 202-210.

Cole, D. A. ve Maxwell, S. E. (2003). Testing Mediational Models With Longitudinal Data: Questions and Tips in the Use of Structural Equation Modeling. Journal of Abnormal Psychology, 112 (4), 558-577.

Corbitt, B.J., Thanasankita, T. ve Yi, H. (2003). Trust and e-commerce: a study of consumer perceptions. Electronic Commerce Research and Applications, 2(3), 203-215.

Çokluk, Ö., Şekercioğlu, G. ve Büyüköztürk, Ş. (2010). Sosyal bilimler için çok değişkenli istatistik SPSS ve LISREL uygulamaları (Birinci Baskı). Ankara: Pegem Yayınc1lı.

Durmuş, B., Ulusu, Y. ve Erdem, Ş. (2013). Which dimensions affect private shopping ecustomer loyalty? 9th International Strategic Management Conference, 27-29 Haziran 2013, Riga, Letonya.

Eid, M.I. (2011). Determinants of E-Commerce Customer Satisfaction, Trust, and Loyalty In Saudi Arabia. Journal of Electronic Commerce Research, 12 (1), 78-93.

E-Commerce News (2015). "Ecommerce in Turkey", http://ecommercenews.eu/ecommerceper-country/ecommerce-turkey/\#market, (21 Mart 2016). 
Gefen, D. ve Straubb, D.W. (2004). Consumer trust in B2C e-Commerce and the importance of social presence: experiments in e-Products and e-Services. Omega, 32, 407-424.

Gorsuch, R. L. (1983). Factor Analysis (Second Edition), Lawrence Erlbaum Associates Publisher: New Jersey, USA.

Haşlaman, T. ve Aşkar, P. (2007). Programlama Dersi İle İlgili Özdüzenleyici Öğrenme Stratejileri ve Başarı Arasındaki İlişkinin İncelenmesi. Hacettepe Üniversitesi Eğitim Fakültesi Dergisi, 32, 110-122.

Hoyle, R.H. (1995). Structural Equation Modeling: Concepts, Issues and Applications, Structural Equation Modeling. USA: Sage, 15.

Internet World Stats. "Internet Usage and Population Statistics", http://www.internetworldstats.com/euro/tr.htm, (9 Mayıs 2016).

Kassim, N.M. ve Abdullah, N.A. (2008). Customer Loyalty in e-Commerce Settings: An Empirical Study. Electronic Markets, 18 (3), 275-290.

Kelloway, E.K. (1998). Using LISREL for Structural Equation Modeling: A Researcher's Guide. USA: Sage.

Kim, D.J., Ferrin, D.L. ve Rao, H.R. (2008). A trust-based consumer decision-making model in electronic commerce: The role of trust, perceived risk, and their antecedents. Decision Support Systems, 44, 544-564.

Light, D.A.(2001). Sure, you can trust us. MIT Sloan Management Review, 43 (1), 17.

MacCallum, R.C.,Widaman, K.F., Zhang, S. And Hong S. (1999). Sample Size in Factor Analysis. Psychological Methods, 4(1), 84-99.

Mukhopadhyay, S., Mahmood, M.A. ve Joseph, J.L. (2008). Measuring Internet-Commerce Success: What Factors are Important? Journal of Internet Commerce, 7(1), 1-28.

Milli Eğitim İstatistikleri. (2016). "Millî Eğitim İstatistikleri Örgün Eğitim 2015-2016 Kitabı" http://sgb.meb.gov.tr/meb_iys_dosyalar/2016_03/30044345_meb_istatistikleri_orgun_egitim 2015_2016.pdf (25 Mart 2017).

Odom, M.D., Kumar, A. ve Saunders, L. (2002). Web assurance seals: how and why they influence consumers' decisions. Journal of Information Systems, 16 (2), 231-250.

Pan, Y., Sheng, S. ve Xie, F.T. (2012). Antecedents of customer loyalty: An empirical synthesis and reexamination. Journal of Retailing and Consumer Services, 19, 150-158.

Pesen, M. M. (2015). "Bilgi Güvenliği Nedir ve Nasıl Sinıflandirılır", https://www.sibergah.com/genel/bilgi-guvenligi-nedir-ve-nasil-siniflandirilir/ (29 Mart 2017).

Poleretzky, Z., Cohn, R. ve Gimnicher, S.M. (January, 1999). The call center ve e-commerce convergence. Call Center Solutions, 76.

Quach, T.N., Thaichon, P. ve Jebarajakirthy, C. (2016). Internet service providers' service quality and its effect on customer loyalty of different usage patterns. Journal of Retailing and Consumer Services, 29, 104-113.

Ramanathan, R. (2011). An empirical analysis on the influence of risk on relationships between handling of product returns and customer loyalty in E-commerce. International Journal Production Economics, 130, 255-261.

Reichheld, F.F., Markey, R.G. ve Hopton, C. (2000). E-customer Loyalty- applying to rules of traditional business for online success. European Business Journal, 173-179.

Srinivasan, S.S., Andersona, R. ve Ponnavolub, K. (2002). Customer loyalty in e-commerce: an exploration of its antecedents and consequences. Journal of Retailing, 78, 41-50.

Sorce, P., Perotti, V. ve Widrick, S. (2005). Attitude and age differences in online buying, International Journal of Retail ve Distribution Management, 33(2), 122-132.

$\mathrm{Su}$, A.Y.L. (2004). Customer satisfaction measurement practice in Taiwan hotels. International Journal of Hospitality Management, 23 (4), 397-408.

SuperOffice (2016). "18 CRM Statistics You Need to Know for 2016", http://www.superoffice.com/blog/crm-software-statistics/, (23 Mayıs 2016). 
Sümer, N. (2000). Yapısal Eşitlik Modelleri: Temel kavramlar ve örnek uygulamalar. Türk Psikoloji Yazlları, 3 (6), 74-79.

Tabachnick, B. G., Fidell, L.S. (2007). Using Multivariate Statistics (5.Bask1). Boston: Pearson/Allyn ve Bacon, 506.

Taylor, W. J., Zhu, G. X., Dekkers, J. ve Marshall, S. (2004). Adoption of online purchasing in communities and its socioeconomic implications in regions central Queensland, Australia. Australasian Journal of Information Systems, 11(2), 80-95.

Tax, S.S., Brown,S.W. ve Chandrashekaran, M. (1998). Customer Evaluations of Service Complaint Experiences: Implications for Relationship Marketing. Journal of Marketing, 62(2), 60-76.

Teo, S.H.H. ve Liu, J. (2007). Consumer trust in e-commerce in the United States, Singapore and China. Omega, 35, 22-38.

Treesinthuros, W. (2012). An Empirical Study of E-commerce Marketing Success. 2012 Tenth International Conference on ICT and Knowledge Engineering, 21-23 Kasim 2012, Bangkok, Tayland.

TÜBİSAD (2014). Yillk Rapor: “Türkiye e-Ticaret Pazar1-2013" http://www.etid.org.tr/haberler/Turkiye-e-ticaret-pazari-buyuklugu-140-Milyar-TL/114/ (25 Mart 2016).

Türkiye İstatistik Kurumu (TÜIK). "Girişimlerde Bilişim Teknolojileri Kullanım Araştırması", http://www.tuik.gov.tr/PreTablo.do?alt_id=1048 (13 Mayıs 2016).

Udo, G.J., Bagchi, K.K. ve Kirs, P.J. (2010). An assessment of customers' e-service quality perception, satisfaction and intention. International Journal of Information Management, 30, 481-492.

Van I. J., Van der Wielea, T., Ball, L. ve Robert Millen, R. (2004). Perceptions about the quality of web sites: A survey amongst students at Northeastern University and Erasmus University, Information ve Management, 41, 947-959.

$\mathrm{Wu}, \mathrm{I}$. (2013). The antecedents of customer satisfaction and its link to complaint intentions in online shopping: An integration of justice, technology, and trust. International Journal of Information Management, 33, 166-176.

Yang, Q., Pang, C., Liu, L., Yen, D. C. ve Tarn, J.M. (2015). Exploring consumer perceived risk and trust for online payments: An empirical study in China's younger generation. Computers in Human Behavior, 50, 9-24.

Yavas, U. (1994). Research note: Students as subjects in advertising and marketing research. International Marketing Review, 11(4), 35-43.

Yılmaz, V. ve Çelik H.E., (2009). LISREL ile Yapısal Eşitlik Modellemesi-1 (Birinci Baskı). Ankara: Pegem Akademi, 29.

Zeithaml, V.A., Parasuraman, A. ve Malhotra, A. (2000). A conceptual framework for understanding e-service quality: Implications for future research and managerial practice. $M S I$ Working Paper Series 00-115:1-49 Cambridge, Massachusetts, ABD. 